\title{
Obituary Otto Hutzinger
}

\author{
Michael McLachlan ${ }^{1 *}$, Karl-Werner Schramm², Dieter Lenoir², Kristina Voigt ${ }^{2}$ and Henner Hollert ${ }^{3}$
}

\begin{abstract}
Otto Hutzinger passed away on September 22, 2012 in Bad Ischl, Austria. He was a scientific pioneer in the field of environmental chemistry and a great architect of the institutions that continue to serve and nurture this discipline. His passing is a great loss to environmental research, especially to the global environmental chemistry community.
\end{abstract}

Otto was born in Vienna, Austria in 1933. After completing an education in chemistry and working for 6 years in the pharmaceutical industry, he and his wife Freda immigrated to Canada in 1958. He studied at the University of Saskatchewan, receiving his PhD in 1965, and he and Freda became Canadian citizens the same year. Following 2 years as a postdoctoral fellow at the University of California, Davis, he joined the National Research Council of Canada, working at their facilities in Halifax. In 1973 he returned to Europe for a sabbatical at the Institute of Ecological Chemistry at the Technical University of Munich. Shortly thereafter, in 1974, he became Professor and Director of the Laboratory of Environmental and Toxicological Chemistry at the University of Amsterdam. The final station in his academic career was as Professor and Chair of Ecological Chemistry and Geochemistry at the University of Bayreuth, Germany from 1983 until his retirement in 1998.

A central milestone in Otto's early research career was his collaboration with Stephen Safe. This meeting of two creative and energetic young scientists was extremely productive, leading to major advances in the understanding of polychlorinated biphenyls, showing the wide variability in their metabolism between congeners and organisms, and producing among other things a paper in Science. Another major highlight was Otto's work with polychlorinated dibenzo- $p$-dioxins and dibenzofurans, whereby his discovery of their presence in flue gas and fly ash from municipal waste incinerators was a catalytic event in the development of this field. Furthermore, already in 1970 and 1980, Otto demonstrated great interest in

\footnotetext{
* Correspondence: michael.mclachlan@itm.su.se

'Department of Applied Environmental Science (ITM), Stockholm University, 10691 Stockholm, Sweden

Full list of author information is available at the end of the article
}

information systems, data analysis, and modeling aspects with respect to the field of environmental chemistry.

After moving back to the university, Otto evolved from being a researcher to creating and fostering research environments. He was extraordinarily successful in this regard. The departments that he built and led in Amsterdam and Bayreuth produced an astonishing number of talented and successful environmental chemists and toxicologists. Many of them went on to take positions of scientific leadership in their fields. Through them, he has disseminated his vision of contaminants research as a multidisciplinary endeavor with an important responsibility to deliver sound science to society and his management philosophy which is centered on generosity, trust, and delegation.

Despite his love for research, Otto discovered that it alone could not satisfy his seemingly boundless creative drive. Later in his career he turned his attention to founding and developing the institutions which support scientific research. As a relatively young discipline, environmental chemistry was in need of this. And what a job Otto did! His long list of accomplishments includes initiating the DIOXIN Conference Series (the 32nd was held this past summer), serving for many years as Editor in Chief of Chemosphere, founding the journals Handbook of Environmental Chemistry, Umweltwissenschaften und Schadstoff-Forschung, and Environmental Science and Pollution Research, starting the section for Environmental Chemistry and Ecotoxicology in the German Chemical Society, starting the company Ökometric, and serving as the founding director of the Bavarian Institute for Waste Research. In one way or another, these activities have impacted environmental chemistry researchers around the world.

But for those of us who knew Otto personally, his greatest legacy is how he touched our lives with his unique 


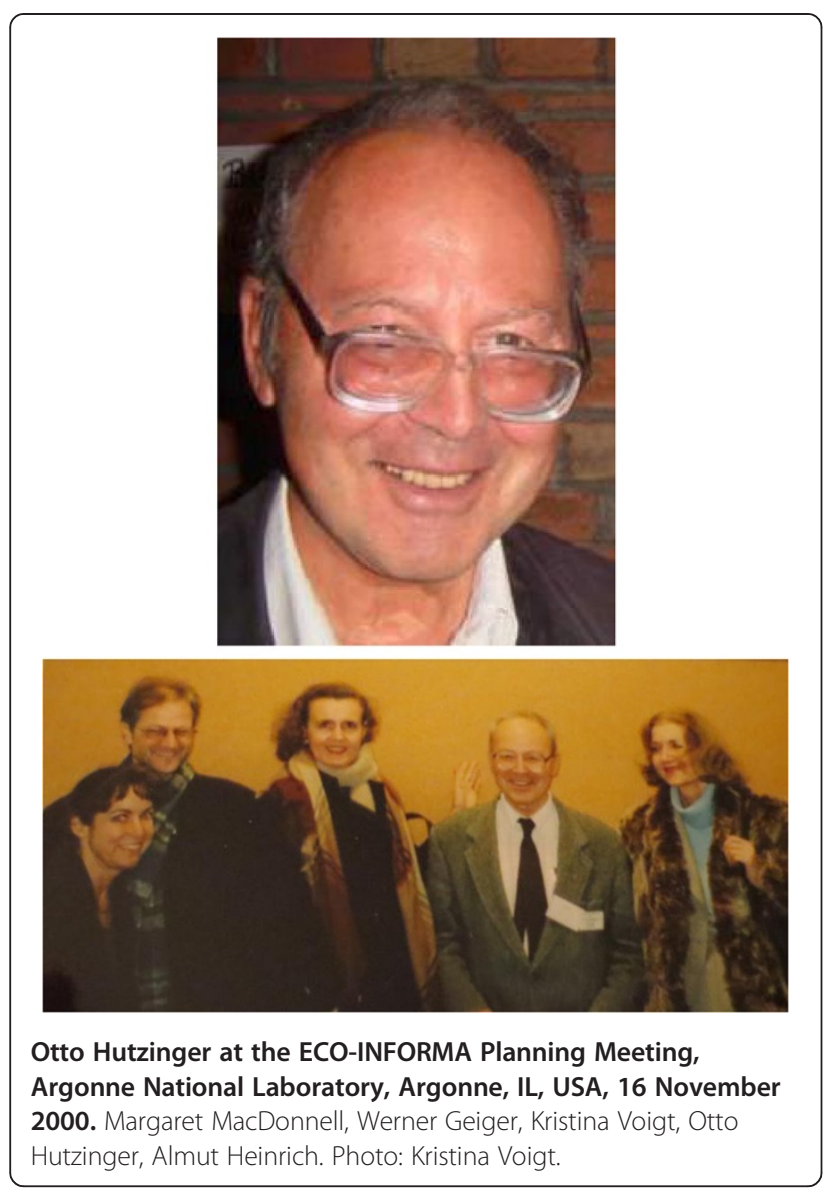

combination of curiosity, creative energy, tolerance, generosity, and kindness.

Find a more detailed obituary written by JP Giesy in [1].

\section{Competing interests}

The authors declare that they have no competing interests.

\section{Authors' contributions}

MM drafted the manuscript. All authors read and approve the final manuscript.

\section{Author details}

'Department of Applied Environmental Science (ITM), Stockholm University, 10691 Stockholm, Sweden. ${ }^{2}$ Helmholtz Zentrum München, German Research Center for Environmental Health $(\mathrm{GmbH})$, Ingolstädter Landstr. 1, 85764 Neuherberg, Germany. ${ }^{3}$ Institute for Environmental Research (Biology V), RWTH Aachen University, Worringerweg 1, 52074 Aachen, Germany.
Received: 25 August 2013 Accepted: 25 August 2013

Published: 20 September 2013

\section{Reference}

1. Giesy JP: Otto Hutzinger: 1932-2012. Toxicol Environ Chem 2012, 94(10):2060-2064. http://dx.doi.org/10.1080/02772248.2012.748134.

doi:10.1186/2190-4715-25-28

Cite this article as: McLachlan et al: Obituary Otto Hutzinger.

Environmental Sciences Europe 2013 25:28.

\section{Submit your manuscript to a SpringerOpen ${ }^{\circ}$ journal and benefit from:}

- Convenient online submission

- Rigorous peer review

- Immediate publication on acceptance

- Open access: articles freely available online

- High visibility within the field

- Retaining the copyright to your article

Submit your next manuscript at $\downarrow$ springeropen.com 